\title{
Brake wear particle emissions: a review
}

\author{
Theodoros Grigoratos • Giorgio Martini
}

Received: 16 July 2014 / Accepted: 6 October 2014 / Published online: 17 October 2014

(C) The Author(s) 2014. This article is published with open access at Springerlink.com

\begin{abstract}
Traffic-related sources have been recognized as a significant contributor of particulate matter particularly within major cities. Exhaust and non-exhaust traffic-related sources are estimated to contribute almost equally to traffic-related $\mathrm{PM}_{10}$ emissions. Non-exhaust particles can be generated either from non-exhaust sources such as brake, tyre, clutch and road surface wear or already exist in the form of deposited material at the roadside and become resuspended due to traffic-induced turbulence. Among non-exhaust sources, brake wear can be a significant particulate matter (PM) contributor, particularly within areas with high traffic density and braking frequency. Studies mention that in urban environments, brake wear can contribute up to $55 \%$ by mass to total non-exhaust traffic-related $\mathrm{PM}_{10}$ emissions and up to $21 \%$ by mass to total traffic-related $\mathrm{PM}_{10}$ emissions, while in freeways, this contribution is lower due to lower braking frequency. As exhaust emissions control become stricter, relative contributions of non-exhaust sources - and therefore brake wear- to traffic-related emissions will become more significant and will raise discussions on possible regulatory needs. The aim of the present literature review study is to present the state-of-the-art of the different aspects regarding PM resulting from brake wear and provide all the necessary information in terms of importance, physicochemical characteristics, emission factors and possible health effects.
\end{abstract}

Keywords Non-exhaust emissions · Brake wear particles . Size distribution - Chemical composition - Emission factors . Health relevance

Responsible editor: Constantini Samara

T. Grigoratos $(\bowtie) \cdot G$. Martini

European Commission, Joint Research Centre, Sustainable Transport

Unit (STU), Institute for Energy and Transport (IET), Via E Fermi

2749, 21027 Ispra, Italy

e-mail: theodoros.grigoratos@jrc.ec.europa.eu

\section{Introduction}

Particles emitted as a result of road transport activity can be distinguished according to their source into exhaust traffic-related particles, which are emitted as a result of incomplete fuel combustion and lubricant volatilization during the combustion procedure, and non-exhaust trafficrelated particles, which are either generated from nonexhaust traffic-related sources or already exist in the environment as deposited material and become resuspended due to traffic-induced turbulence. Exhaust particles have been very well studied and characterized, while technological improvements have resulted in a significant reduction of their emissions (Amato et al. 2014; Denier Van der Gon et al. 2013; Pant and Harrison 2013). On the other hand, non-exhaust processes have not yet been adequately studied, and several questions regarding physicochemical characteristics, emission factors and possible adverse health effects of wear particles still remain unanswered (Denier Van der Gon et al. 2013). The most important abrasion processes which result in direct particulate matter (PM) emission are tyre, brake, clutch and road surface wear, with other potential sources being engine wear, abrasion of wheel bearings and corrosion of other vehicle components, street furniture and crash barriers (Barlow et al. 2007; Boulter 2006; Pant and Harrison 2013; Thorpe and Harrison 2008). Besides direct traffic-related sources, non-exhaust PM exists due to resuspension of material already deposited on the road surface as a result of tyre shear, vehiclegenerated turbulence, and the action of the wind. Road dust resuspension can be a significant contributor of PM especially in dryer climates (Abu-Allaban et al. 2003; Amato et al. 2009; Amato et al. 2010).

In the case of road transport, there is a general conviction that most primary fine particles are emitted from the exhaust, whereas many of the coarse particles are considered to 
originate from non-exhaust sources. This is not precise since there is much evidence that non-exhaust particles contribute to both the fine and coarse modes of $\mathrm{PM}_{10}$ (Amato et al. 2014; Boulter 2006; Dahl et al. 2006; Denier Van der Gon et al. 2013; Gustafsson et al. 2008; Harrison et al. 2012; Kukutschová et al. 2011; Kumar et al. 2013; Mathissen et al. 2011). There are numerous studies reporting that exhaust and non-exhaust traffic-related sources contribute almost equally to total trafficrelated $\mathrm{PM}_{10}$ emissions, while due to continuous reduction of exhaust emissions, it is expected that the relative contribution of non-exhaust sources will increase in the forthcoming years (Amato et al. 2011; Amato et al. 2014; Bukowiecki et al. 2009a; Denby et al. 2013; Denier Van der Gon et al. 2013; Ketzel et al. 2007; Pant and Harrison 2013; Querol et al. 2004). One of the most important non-exhaust traffic-related source is considered to be brake wear, with studies at urban environments reporting contribution to non-exhaust traffic-related $\mathrm{PM}_{10}$ emissions up to $55 \%$ by mass (Harrison et al. 2012) and to total traffic-related $\mathrm{PM}_{10}$ emissions up to $21 \%$ by mass (Bukowiecki et al. 2009a; Gasser et al. 2009; Lawrence et al. 2013). On the other hand, it is more difficult to extract precise estimations on the contribution of brake wear to ambient $\mathrm{PM}_{10}$ concentrations since this contribution depends on various other parameters besides the sampling location. However, there are studies which have revealed brake wear contributions to ambient $\mathrm{PM}_{10}$ concentrations varying from negligible to up to $4 \mu \mathrm{g} \mathrm{m}^{-3}$ (Amato et al. 2009; Bukowiecki et al. 2009a; Denier Van der Gon et al. 2007; Furusjö et al. 2007; Harrison et al. 2012; Sjödin et al. 2010; Wåhlin et al. 2006).

Several difficulties arise when studying particles from nonexhaust traffic-related sources and particularly from brake wear. Probably the most important restriction has to do with the lack of standardized sampling procedure and measurement techniques. This often leads in different experimental approaches by researchers and therefore in non-comparable results and conclusions. Several studies have shown that brake wear debris differs depending on the bulk friction material (Kukutschová et al. 2011; Österle et al. 2001). Additionally, brake wear particles' chemical composition and emission rates largely depend on the driving behaviour and more particularly on the frequency and severity of braking (Kwak et al. 2013). Vehicle's speed, condition and maintenance history can also be important parameters. Finally, the conditions under which the braking event occurs (ambient temperature and chemicals available in the environment) can have a big impact on the characteristics of the generated particles (Barlow et al. 2007; Boulter 2006; Boulter et al. 2006; Kukutschová et al. 2011; Mosleh et al. 2004; Olofsson and Olander 2013).

Despite the difficulties in measuring and characterizing brake wear particles, an increasing number of researchers and experts have already raised a discussion on the need for regulating emissions from non-exhaust sources including brake wear (Amato et al. 2014; Denier Van der Gon et al.
2013). The aim of the present literature review is to present the state-of-the-art of the different aspects regarding PM resulting from brake wear and provide all the necessary information in terms of importance, physicochemical characteristics, emission factors and possible adverse health effects. Also, this study aims in identifying the major gaps regarding the above-mentioned issues since it is necessary to take them into account in order to assess the possible need for regulating brake wear emissions.

\section{General information and importance of brake wear particles}

Two brake system configurations have been widely used in modern passenger vehicles: disc brakes, in which flat brake pads are forced against a rotating metal disc (Fig. 1), and drum brakes, in which curved brake shoes are forced against the inner surface of a rotating cylinder. Modern passenger vehicles are usually equipped with disc front and rear brakes, while in the past, drum brakes were usually employed as rear brakes. It is estimated that front brakes have to provide approximately $70 \%$ of total braking power and therefore have to be replaced more frequently than rear ones. The majority of car braking systems consist of frictional pairs made of a disc, a pad and a calliper. Figure 1 depicts a disc brake assembly with a single-piston floating calliper and a ventilated rotor (Wahlström 2009). Rotors used in passenger vehicles are usually made of grey cast iron, but in some cases, they can be made of composites such as reinforced carbon-carbon, ceramic matrix composites and aluminum.

Brake linings generally comprise five main components: binders, fibres, fillers, frictional additives or lubricants and abrasives (Boulter 2006; Chan and Stachowiak 2004; Kukutschová et al. 2011; Thorpe and Harrison 2008; Wahlström 2009; Wahlström 2011). Binders hold the components of the brake pad together and ensure the structural integrity of the lining under mechanical and thermal stress.

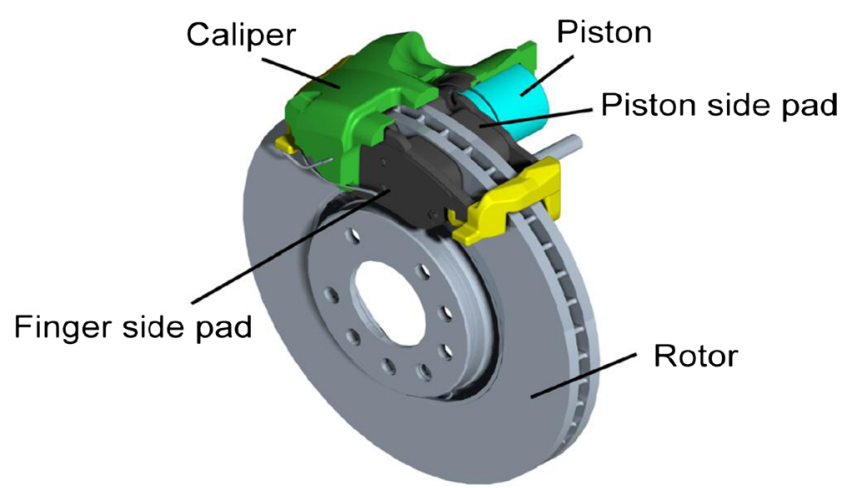

Fig. 1 Graphic representation of a disc brake system. Source: [Wahlström 2009] 
They account for $20-40 \%$ of the lining material and are made of modified phenol-formaldehyde resins. Reinforcing fibres provide mechanical strength and structure to the lining. They usually account for $6-35 \%$ (by mass) of the lining material and can be classified as metallic, mineral, ceramic or organic. They mainly consist of copper, steel, brass, potassium titanate, glass, organic material and Kevlar. Fillers are used in order to improve thermal and noise pad properties and also reduce the manufacturing cost. They usually consist of inorganic compounds (barium and antimony sulphate, magnesium and chromium oxides), silicates, ground slag, stone and metal powders and account between 15 and $70 \%$ (by mass) of the lining material. Lubricants influence the wear characteristics of the lining. They can be inorganic, metallic or organic. Graphite is usually employed, but other common materials include ground rubber, metallic particles, carbon black, cashew nut dust and antimony trisulphide. They usually make up 5-29 \% by mass of the brake lining. Abrasives are used in order to increase friction, maintain cleanliness between contact surfaces and limit the buildup of transfer films. They typically account for up to $10 \%$ by mass of the lining. Aluminum oxide, iron oxides, quartz and zircon are the most common abrasive constituents. The proportions of the abovementioned components vary according to the type of lining and the manufacturer (Boulter et al. 2006; Eriksson et al. 2001). Three different lining types are usually found in passenger vehicles: non-asbestos organic (NAO), semimetallic and low metallic. NAO-type pads are relatively soft and exhibit low brake noise compared to other types of pads, but they lose braking capacity at high temperature and create more dust than the other types. For many years, brake linings were composed of asbestos fibres, while today, they are asbestos free due to serious health concerns (Lemen 2004; Liew and Nirmal 2013; Roubicek et al. 2008; Thorpe and Harrison 2008). Low-metallic pads comprise organic compounds mixed with small amounts of metals (10$30 \%$ by mass). They exhibit high friction and good braking capacity at high temperatures. Semimetallic brake pads have higher metallic content (up to $65 \%$ by mass), which makes them more durable and with excellent heat transfer. On the other hand, they tend to wear down rotors faster and exhibit intrusive noise characteristics. For high performance requirements, or extreme braking conditions (sports cars, ambulances, police cars), metallic linings which contain steel and copper fibres are employed.

The frictional contact between the disc and the pad generates particles of various sizes. During a braking event, the calliper acts mechanically on the pad, which slides against the disc and transforms vehicle kinetic energy into thermal energy. Apart from the mechanical abrasion, vehicle brakes become subject to large frictional heat generation with subsequent wear of linings and rotors. This generates mostly micron-sized particles. Figure 2 shows particles of different sizes generated as a result of brake wear tests performed in the laboratory (Kukutschová et al. 2011). Finally, some disc-brake systems require the pads to be in low-pressure contact with the rotor in order to ensure robust brake performance. This leads in higher particle release in the environment (Söderberg et al. 2008). A detailed explanatory model of the complex contact situation between an organic brake pad and a cast iron disc has been developed and published by some researchers (Eriksson et al. 2002; Österle et al. 2001; Ostermeyer 2001). In this model, the macroscopic friction and wear behaviour of a disc brake can be explained by the microscopic contact situation (growth and destruction of contact plateaus) in the boundary layer between the pad and disc. Wahlström (2011) provided a simplified visual explanation of the model which is given in Fig. 3. It has been shown that the plateau surface is covered by a nanocrystalline third body formed by the wear particles and that this third body is mainly made of iron oxides (Österle and Urban 2006). The third body differs in structure composition and properties from the two first bodies, pad and disc in our case (Oesterle and Dmitriev 2014). Much detailed work has been published on this field by several researchers (Bodel and Ostermeyer 2014; Ostermeyer 2007; Ostermeyer and Muller 2008).

Not all wear debris generated during braking become airborne. Approximately $50 \%$ of wear particles lie into diameters smaller than $20 \mu \mathrm{m}$ (Barlow et al. 2007; Garg et al. 2000; Kukutschová et al. 2011; Sanders et al. 2003), while almost $40 \%$ of brake wear debris is emitted as $\mathrm{PM}_{10}$ (Garg et al. 2000; Harrison et al. 2012; Kumar et al. 2013; Kukutschová et al. 2011; Mosleh et al. 2004; Sanders et al. 2003; Wik and Dave 2009). The rest may deposit on the road surface or be
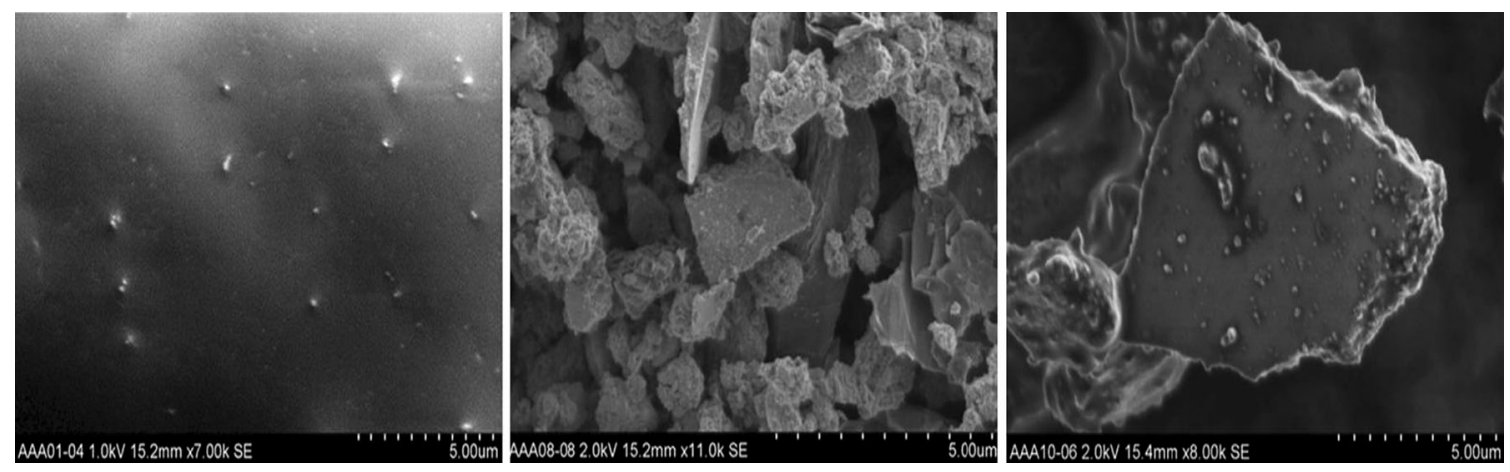

Fig. 2 SEM images of brake wear particles (left $<56$ nm, middle $\mathrm{PM}_{2.5}$, right $\mathrm{PM}_{10}$ ). Source: [Kukutschová et al. 2011] 


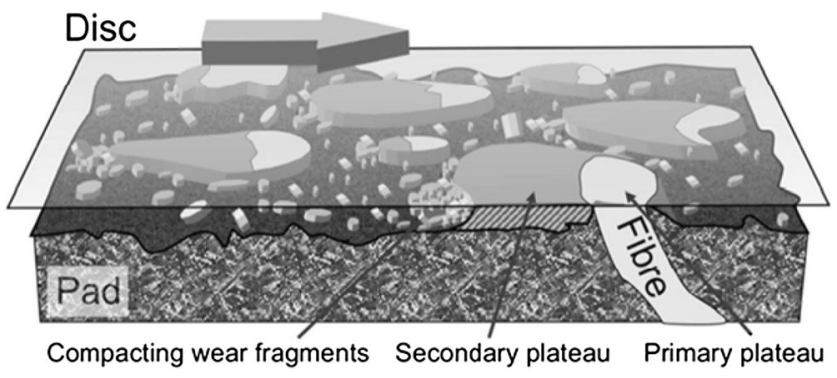

Fig. 3 Illustration of the contact situation between the pad and disc. A transparent disc is moving from left to right. Some of the wear particles pile up against the contact plateaus and create secondary plateaus. A flow of wear particles in the gap between the pad and disc wear the lowlands of the pad through three-body abrasion. Source: [Wahlström 2011]

attracted to the vehicle with its fate remaining unknown. It is easily understood that the highest concentrations of brake wear particles are observed near busy junctions, traffic lights, pedestrian crossings and corners, even if wear particles may also be released from the brake mechanism some time after the primary emission event (Kennedy et al. 2002). Several studies at urban environments have reported contribution of brake wear particles to non-exhaust traffic-related $\mathrm{PM}_{10}$ emissions ranging between 16 and $55 \%$ by mass (Bukowiecki et al. 2009a; Gasser et al. 2009; Harrison et al. 2012; Lawrence et al. 2013; Riediker et al. 2008), while significantly lower contributions ( $\sim 3 \%$ by mass) have been reported in highways where braking events are less frequent (Abu-Allaban et al. 2003; Bukowiecki et al. 2009a). Additionally, studies have revealed contributions of brake wear to total traffic-related $\mathrm{PM}_{10}$ emissions of 11-21\% by mass (Bukowiecki et al. 2009a; Gasser et al. 2009; Lawrence et al. 2013). On the other hand, brake wear contributions to ambient $\mathrm{PM}_{10}$ concentrations vary from negligible to up to $4 \mu \mathrm{g} \mathrm{m}^{-3}$ (Amato et al. 2009; Bukowiecki et al. 2009a; Denier Van der Gon et al. 2007; Harrison et al. 2012; Wåhlin et al. 2006). Taking into consideration the general decreasing tendency of engine exhaust emissions due to the use of catalytic converters, diesel particulate filters (DPF) and improved fuels and engines, it is expected that the relative contribution of brake wear particles to the total PM levels will increase in the forthcoming years making the need for characterization of these particles urgent (Amato et al. 2014; Denier Van der Gon et al. 2013; Pant and Harrison 2013; Wik and Dave 2009).

\section{Brake wear particle mass distribution}

Although brake wear particles are emitted as a result of a predominantly mechanical process and are expected to lie mainly into the coarse size fraction, there are many studies which have shown high particle concentrations also in the fine and ultrafine fractions (Garg et al. 2000; Kukutschová et al. 2011; Kwak et al. 2013; Iijima et al. 2007; Riediker et al.
2008; Sanders et al. 2003; von Uexküll et al. 2005; Wahlström et al. 2010b). SEM images of brake wear particles demonstrated that ultrafine and some of the fine particles seem to be smoother with fewer sharp edges compared to bigger particles, thus pointing to thermal and/or chemical generation processes (Wahlström et al. 2010a). This can be a result of high temperatures at the brake/rotor interface which lead in the decomposition of brake lining materials. Garg et al. (2000) tested different brake pads and found that 86 and $63 \%$ of the brake wear airborne particle mass was distributed in the $\mathrm{PM}_{10}$ and $\mathrm{PM}_{2.5}$, respectively. Surprisingly, a considerable $33 \%$ (by mass) of wear particles was found into diameters smaller than $0.1 \mu \mathrm{m}$. Similarly, Sanders et al. (2003) tested different brake pads and found that $\mathrm{PM}_{10}$ accounted for $63-85 \%$ of the total brake wear mass, depending on the type of pad. Iijima et al. (2008) reported that 56-70\% of total brake wear mass generated from three different NAO pads was emitted as $\mathrm{PM}_{2.5}$, while 95-98 \% was emitted as $\mathrm{PM}_{10}$. Similar distributions (98 and $39 \%$ for $\mathrm{PM}_{10}$ and $\mathrm{PM}_{2.5}$, respectively) are extracted by the EMEP/CORINAIR Emissions Inventory Guidebook (Thorpe and Harrison 2008). On the other hand, receptor modelling studies showed that brake wear contribution was significantly higher in $\mathrm{PM}_{10}$ than in $\mathrm{PM}_{2.5}$ fraction (Abu-Allaban et al. 2003).

Studies dealing with brake wear particle characterization can be distinguished in those which the collection and characterization of particles take place in the laboratory by means of brake dynamometer tests (Garg et al. 2000; Gasser et al. 2009; Kukutschová et al. 2011; Iijima et al. 2007; Iijima et al. 2008; Mosleh et al. 2004; Sanders et al. 2003; Sondhi et al. 2010; Wahlström et al. 2010b), those which the collection and characterization of particles are performed in ambient air and then brake wear emissions are identified by means of specific brake wear tracers (Bukowiecki et al. 2009a; Bukowiecki et al. 2009b; Dongarra et al. 2009; Gietl et al. 2010; Harrison et al. 2012; Hjortenkrans et al. 2007; Fabretti et al. 2009; Sondhi et al. 2010; Wåhlin et al. 2006) and those which brake wear particles are directly sampled on-road under "realworld" driving conditions by means of mobile units (Mathissen et al. 2011). In Fig. 4, a schematic representation of the assembly used in brake dynamometer studies is provided (Kukutschová et al. 2011; Iijima et al. 2008). On the right, an open sampling system is depicted, while on the left, the sampling system is closed. Table 1 provides an overview of the most important literature studies dealing with the characterization of brake wear particles in terms of their mass size distribution.

Most researchers have found unimodal brake wear $\mathrm{PM}_{10}$ mass distributions with maxima ranging between 1.0 and $6.0 \mu \mathrm{m}$. For instance, Sanders et al. (2003) tested low-metallic, semimetallic and NAO pads under typical urban driving conditions and found unimodal $\mathrm{PM}_{10}$ distribution with a mass-weighted mean diameter of 5-6 $\mu \mathrm{m}$, while Iijima et al. 

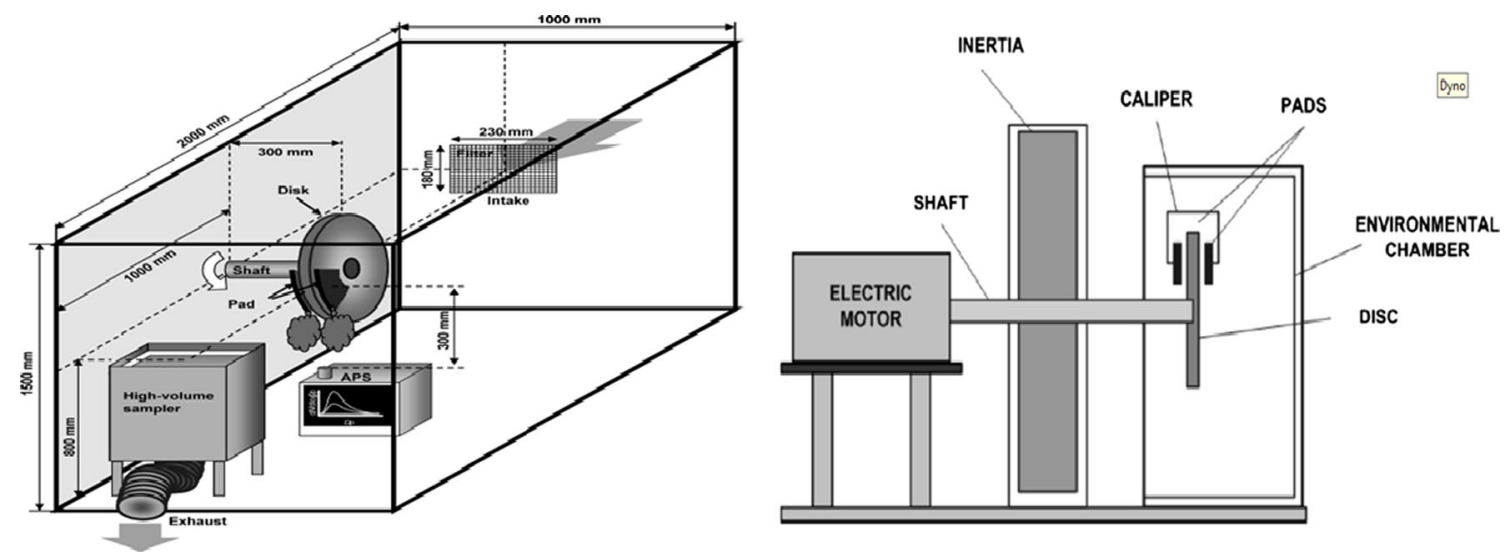

Fig. 4 Schematic representation of the brake dynamometer assembly. Sources: [left Iijima et al. 2008; right Kukutschová et al. 2011]

(2007) tested NAO pads and found a unimodal distribution with a slightly lower mass-weighted mean diameter $(3-6 \mu \mathrm{m})$. Both studies were carried out in an open sampling system (like the one shown in Fig. 4 on the right); therefore, the particle size distribution could not deviate from the original due to particle aggregation or deposition as a result of the interaction between the particles and the chamber wall. This effect has been described in case of close systems (Iijima et al. 2007). Iijima et al. (2007) reported that increasing disc temperature results in a slight shift of the mass distribution curve towards higher sizes. A similar observation was made by Mosleh et al. (2004) in the case of brake wear particle number distribution. Other studies also revealed unimodal mass distributions with however somewhat lower mass-weighted mean diameter. For instance, Kukutschová et al. (2011) tested low-metallic pads and found unimodal distribution with maxima at 2-4 $\mu \mathrm{m}$, while von Uexküll et al. (2005) conducted tests on front and rear truck brakes and found unimodal mass distributions with maxima at $2-3 \mu \mathrm{m}$. An on-road experimental campaign conducted by Harrison et al. (2012) reached similar conclusions to brake dynamometer studies. Harrison et al. (2012) collected size-fractionated samples of airborne PM and used the size distribution of specific tracer elements in order to estimate the contribution of brake wear to particle mass. They found that brake wear particles appeared a unimodal $\mathrm{PM}_{10}$ mass distribution with a peak at $2-3 \mu \mathrm{m}$.

\section{Brake wear particle number distribution}

Number size distribution of brake wear particles is of high importance since a significant amount of the generated particles is distributed among smaller sizes. Most researchers report at least one peak of the number size distribution at the ultrafine fraction. Garg et al. (2000) conducted brake dynamometer tests and found the highest number of emitted particles to lie into diameters smaller than $30 \mathrm{~nm}$. This is in agreement with Mathissen et al. (2011) who conducted a road simulation study and found that wear particles generated at $100 \mathrm{~km} \mathrm{~h}^{-1}$ full stop braking events exhibited a bimodal particle number $(\mathrm{PN})$ distribution with a nucleation mode at $10 \mathrm{~nm}$ and a second mode between 30 and $50 \mathrm{~nm}$. Thirty kilometers per hour full stop braking events led to unimodal size distributions with slightly shifted maxima towards larger diameters (70-90 nm). Kukutschová et al. (2011) found that despite the fact that the generation of small wear particles

Table 1 Overview of literature studies investigating the mass distribution of airborne brake wear particles

\begin{tabular}{lllll}
\hline Reference & Type of study & Brake pads tested & Method & Mass size distribution \\
\hline Cha et al. 1983 & Brake dynamometer & Asbestos & & Unimodal $(2.1-3.3 \mu \mathrm{m})$ \\
Garg et al. 2000 & Brake dynamometer & Semimetallic and NAO & MOUDI $(>0.1 \mu \mathrm{m})$ & Unimodal $(0.1-1.0 \mu \mathrm{m})$ \\
Sanders et al. 2003 & Brake dynamometer & Low metallic, semimetallic and NAO & MOUDI-ELPI & Unimodal $(4-5 \mu \mathrm{m})$ \\
von Uexküll et al. 2005 & Brake dynamometer & Disc and drum (trucks $)$ & Optical particle counter $(>0.3 \mu \mathrm{m})$ & Unimodal $(2-3 \mu \mathrm{m})$ \\
Iijima et al. 2007 & Brake dynamometer & NAO & APS $(>0.5 \mu \mathrm{m})$ & Unimodal $(3-6 \mu \mathrm{m})$ \\
Iijima et al. 2008 & Brake dynamometer & NAO & APS $(>0.5 \mu \mathrm{m})$ & Unimodal $(2.0 \mu \mathrm{m})$ \\
Kukutschová et al. 2011 & Brake dynamometer & Low metallic & APS-SMPS-BLPI & Unimodal $(2-4 \mu \mathrm{m})$ \\
Harrison et al. 2012 & On-road measurement & Roadside PM & MOUDI & Unimodal $(2-3 \mu \mathrm{m})$ \\
Kwak et al. 2013 & On-road measurement & Roadside PM & APS $(>0.5 \mu \mathrm{m})$ & Unimodal $(1-10 \mu \mathrm{m})$ \\
\hline
\end{tabular}


$(<500 \mathrm{~nm})$ at low rotor temperature conditions was negligible, the concentration of nanoparticles smaller than $100 \mathrm{~nm}$ significantly increased with the increase of the cast iron disc temperature (up to $340{ }^{\circ} \mathrm{C}$ ). They proposed that submicron particles are rather formed by the evaporation/condensation process with subsequent aggregation of primary nanoparticles than by an abrasive type of wear. Wahlström et al. (2010b) also noted a peak in the particle number distribution at approximately $100 \mathrm{~nm}$, and they found a shift of the PN distribution towards lower sizes when front brakes were tested (compared to rear brakes). Riediker et al. (2008) tested pad materials of six different passenger cars under controlled environmental conditions and found a bimodal PN distribution with peaks at $80 \mathrm{~nm}$ (depending on the tested car and braking behaviour) and at $200-400 \mathrm{~nm}$. They found that full stops result in higher nanoparticle production compared to normal deceleration. Table 2 provides an overview of the most important literature studies dealing with the characterization of brake wear particles in terms of their number distribution.

Not all studies found ultrafine brake wear particles. There are several studies which show particle number distribution with the first peak at approximately $300 \mathrm{~nm}$. Wahlström et al. (2010a) tested low-metallic and NAO pads and found a bimodal number size distribution with peaks at approximately 280 and $350 \mathrm{~nm}$. However, this could be due to instrument's limitation on the size of sampling particles $(>0.30 \mu \mathrm{m})$. Mosleh et al. (2004) tested a commercial truck semimetallic pad and found a bimodal PN distribution with a peak at approximately $350 \mathrm{~nm}$, regardless the sliding speed and the nominal contact pressure, and another at higher particle sizes $(\sim 2.0 \mu \mathrm{m})$. They found that the second peak is related to the applied nominal contact pressure and sliding speed, and they concluded that fine wear particles originate from the cast iron disc, whereas coarse particles mainly come from the brake pad material. Wahlström et al. (2010b) used a pin-on-disc tribometer in order to test airborne wear debris generated from the interaction of NAO and low-metallic pads with grey cast iron rotors. They reported that low-metallic pads result in higher wear rates of the rotor material than NAO pads and thus in higher concentrations of airborne wear particles. In all cases, similar PN distributions with maxima at around 280, 350 and $550 \mathrm{~nm}$ were observed.

Finally, there are some studies which report PN distributions with the first peak at approximately $1.0 \mu \mathrm{m}$. For instance, Sanders et al. (2003) conducted dynamometer and on-road vehicle tests in three different classes of lining materials and found a maximum peak at approximately $1.0 \mu \mathrm{m}$. Iijima et al. (2007) used an APS spectrometer (measured particles $>0.50 \mu \mathrm{m}$ ) in order to investigate the PN distribution from NAO brake pads and found the peak at $1.0 \mu \mathrm{m}$. They also observed a tendency of shifting of the distribution to coarser sizes with increasing disc temperature. Overall, brake wear particle number distributions usually appear to be bimodal with both peaks lying within the fine particle mode.

\section{Chemical characterization of brake wear particles}

Chemical composition of brake wear particles should be taken into account when trying to fully characterize them and assess their possible adverse effects on human health. Several epidemiology studies have correlated adverse health responses with the presence of specific chemical species like carbonaceous material (Kelly and Fussell 2012; Lipfert et al. 2006; Ostro et al. 2006; WHO 2013) and trace elements (heavy metals) (Kelly and Fussell 2012; Ostro et al. 2007; Pope et al. 2007) in the ambient PM.

Modern brakes are composites of many different and sometimes unknown ingredients, and even if the chemical composition of brake wear debris significantly differs from the chemical composition of the original lining material

Table 2 Overview of literature studies investigating the number distribution of airborne brake wear particles

\begin{tabular}{|c|c|c|c|c|}
\hline Reference & Type of study & Brake pads tested & Method & Particle number distribution \\
\hline Sanders et al. 2003 & Brake dynamometer & $\begin{array}{l}\text { Low metallic, semimetallic } \\
\text { and NA004F }\end{array}$ & ELPI & Unimodal $(1.0 \mu \mathrm{m})$ \\
\hline Mosleh et al. 2004 & Brake dynamometer & Semimetallic (truck) & Laser scattering analyser & Bimodal $(350 \mathrm{~nm}$ and $2.0 \mu \mathrm{m})$ \\
\hline von Uexküll et al. 2005 & Brake dynamometer & Disc and drum (trucks) & Optical particle counter $(>0.3 \mu \mathrm{m})$ & Unimodal $(0.5-1.0 \mu \mathrm{m})$ \\
\hline Iijima et al. 2007 & Brake dynamometer & $\mathrm{NAO}$ & APS $(>0.5 \mu \mathrm{m})$ & Unimodal $(1.0-2.0 \mu \mathrm{m})$ \\
\hline Riediker et al. 2008 & Brake dynamometer & $\begin{array}{l}\text { Vehicles under different } \\
\text { driving conditions }\end{array}$ & TEM & Bimodal (80 and $400 \mathrm{~nm})$ \\
\hline Iijima et al. 2008 & Brake dynamometer & $\mathrm{NAO}$ & APS $(>0.5 \mu \mathrm{m})$ & Unimodal $(0.8-1.0 \mu \mathrm{m})$ \\
\hline Wahlström et al. 2010a & Brake dynamometer & Low metallic and NAO & GRIMM $(>0.25 \mu \mathrm{m})$ & Bimodal (280 and $350 \mathrm{~nm})$ \\
\hline Wahlström et al. $2010 \mathrm{~b}$ & Brake dynamometer & Low metallic and NAO & GRIMM-SMPS & Multimodal (100-550 nm) \\
\hline Mathissen et al. 2011 & $\begin{array}{l}\text { On-road direct } \\
\text { measurement }\end{array}$ & $\begin{array}{l}\text { Vehicle under different } \\
\text { driving conditions }\end{array}$ & EEPS $(<0.56 \mu \mathrm{m})$ & Bimodal (10 and $40 \mathrm{~nm})$ \\
\hline Kukutschová et al. 2011 & Brake dynamometer & Low-metallic brake pads & APS-SMPS & Bimodal (100 and $300 \mathrm{~nm}$ ) \\
\hline
\end{tabular}


(Kukutschová et al. 2011; Österle et al. 2001), someone has to look into both linings and wear debris composition in order to gain a comprehensive view of how the braking process affects the chemical composition of brake wear particles. Despite the large variation in the chemical composition of commercial lining materials, most researchers have reported $\mathrm{Fe}, \mathrm{Cu}, \mathrm{Zn}$ and $\mathrm{Pb}$ to be the most abundant metals in the brake lining (Chan and Stachowiak 2004; Figi et al. 2010; Gadd and Kennedy 2000; Kukutschová et al. 2011; Iijima et al. 2007; Schauer et al. 2006; von Uexküll et al. 2005; Westerlund 2001). Fe content can reach up to $60 \mathrm{wt} . \%$ and varies according to the type of lining (Chan and Stachowiak 2004; Gadd and Kennedy 2000; Kukutschová et al. 2011; Schauer et al. 2006). Cu and Zn follow at relatively high concentrations (Iijima et al. 2007; von Uexküll et al. 2005; Westerlund 2001), with K and Ti also being present at considerable concentrations. Significant $\mathrm{Pb}$ content (up to $12 \mathrm{wt} . \%$ ) has been reported in older studies (Thorpe and Harrison 2008), with however latest studies showing a remarkable decrease (0.2 wt.\%, Kukutschová et al. 2011) due to the replacement of $\mathrm{Pb}$ in modern linings (Bukowiecki et al. 2009a). Other metals such as $\mathrm{Ba}, \mathrm{Mg}, \mathrm{Mn}, \mathrm{Ni}, \mathrm{Sn}, \mathrm{Cd}, \mathrm{Cr}, \mathrm{Ti}, \mathrm{K}$ and $\mathrm{Sb}$ have also been found in concentrations lower than $0.1 \mathrm{wt} . \%$ (Boulter 2006; Kukutschová et al. 2011; Thorpe and Harrison 2008). Recently, brake wear emissions have been cited as a potentially important source of Sb. Brake linings contain 1-5\% $\mathrm{Sb}$ in the form of stibnite $\left(\mathrm{Sb}_{2} \mathrm{~S}_{3}\right)$, which is employed as a lubricant in order to reduce vibrations and improve friction stability. Roubicek et al. (2008) tested linings from different geographic regions and found European and Japanese samples to contain $\mathrm{Sb} \mathrm{S}$. Stibnite can be oxidized during the braking process to $\mathrm{Sb}_{2} \mathrm{O}_{3}$, which has been categorized as a potentially carcinogenic substance (Varrica et al. 2013; Von Uexküll et al. 2005). Very limited information regarding the presence of organic compounds is available in the literature (Gadd and Kennedy 2000; Rogge et al. 1993). Gadd and Kennedy (2000) examined six different commercial brake pads and found phenolic compounds to be the most abundant species present in the brake pad extracts. They also found carbonyl compounds, organic acids, methyl-esters and aromatic carboxylic acids in trace concentrations.

Chemical properties of the parent lining material are often modified due to high temperatures and pressures reached during the braking process. However, brake wear is characterized by a specific pattern of some heavy metals $(\mathrm{Fe}, \mathrm{Cu}, \mathrm{Zn}$, $\mathrm{Sn}, \mathrm{Sb}$ ) in the airborne PM concentrations (Boulter 2006; Bukowiecki et al. 2009a), which are similar to those of the lining material. These elements have been extensively used as specific tracers for brake wear. Wahlström et al. (2010a) conducted a brake dynamometer study and found that fine wear particles mainly comprised $\mathrm{Fe}, \mathrm{Cu}, \mathrm{Ti}, \mathrm{Al}$ as well as oxygen and carbonaceous species. On the other hand, coarse particles appeared as flakes and mainly comprised $\mathrm{Fe}$ in the form of its oxides. They concluded that these particles were mechanically generated suggesting disc wear. Some of the coarse particles also contained $\mathrm{Ti}, \mathrm{Cu}$ and $\mathrm{Al}$ and were attributed to the brake pads. Kukutschová et al. (2011) tested low-metallic brake pads and reported that the finest brake wear PM fraction was dominated by metallic and carbonaceous species. Fe dominated metallic content in both fine and coarse fractions, while TEM analysis revealed the presence of maghemite $\left(\gamma-\mathrm{Fe}_{2} \mathrm{O}_{3}\right)$, magnetite $\left(\mathrm{FeO}-\mathrm{Fe}_{2} \mathrm{O}_{3}\right)$ and amorphous carbon in the nanoparticle fraction and maghemite, magnetite, and hematite $\left(\alpha-\mathrm{Fe}_{2} \mathrm{O}_{3}\right)$ in the fine fraction. $\mathrm{Cu}, \mathrm{Sn}, \mathrm{S}$ and $\mathrm{Zn}$ were also present in various oxide forms. Similar results were obtained by Peikertová et al. (2013) who additionally detected MoS. Napier et al. (2008) conducted a meta-analysis of data collected in the UK and recognized brake wear as the largest single source of atmospheric $\mathrm{Cu}$. Regarding carbonaceous species, carbon black was attributed to the oxidative wear and subsequent deposition from related volatiles (Yu et al. 2009), while graphitic particles were emitted as a result of abrasive wear. Similarly, Gasser et al. (2009) found high concentrations of $\mathrm{Fe}, \mathrm{Cu}$ and $\mathrm{OC}$, in both "normal deceleration" and "full stop" braking patterns. $\mathrm{Fe}, \mathrm{Cu}$ and $\mathrm{Mn}$ significantly correlated between each other suggesting their common brake wear origin. They also found that $\mathrm{OC}$ was present in one order of magnitude higher concentrations compared to EC (Riediker et al. 2008). Garg et al. (2000) found average trace element percent in total $\mathrm{PM}_{10}$ mass of $72 \%$ with $\mathrm{Fe}, \mathrm{Cu}, \mathrm{Ti}, \mathrm{S}$ and $\mathrm{Zr}$ being the most abundant. Over $96 \%$ of the total carbon mass was attributed to organic substances in agreement with Riediker et al. (2008). Regarding the presence of $\mathrm{Sb}$ in airborne $\mathrm{PM}$, existing studies seem to have reached contradictory conclusions. Some researchers reported the absence of $\mathrm{Sb}$ in airborne wear particles (Kukutschová et al. 2011; Wahlström et al. 2010a), which is supported by the intention of brake manufacture companies to substitute $\mathrm{Sb}$ in modern brake linings von Uexküll et al. (2005). On the other hand, Varrica et al. (2013) concluded that Sb

Table 3 Trace element concentrations found in emitted brake wear dust

\begin{tabular}{llll}
\hline Metal & Brake dust $(\mathrm{mg} / \mathrm{kg})$ & Metal & Brake dust $(\mathrm{mg} / \mathrm{kg})$ \\
\hline $\mathrm{Al}$ & $330-20,000$ & $\mathrm{Mg}$ & $(1700)-83,000$ \\
$\mathrm{As}$ & $<2.0-(110)$ & $\mathrm{Mn}$ & $620-5640$ \\
$\mathrm{Ba}$ & $(5800)-140,000$ & $\mathrm{Mo}$ & $5.0-740$ \\
$\mathrm{Ca}$ & $500-8600$ & $\mathrm{Na}$ & $80-(5100)$ \\
$\mathrm{Cd}$ & $<0.06-11$ & $\mathrm{Ni}$ & $80-730$ \\
$\mathrm{Co}$ & $12-42.4$ & $\mathrm{~Pb}$ & $4.0-1290$ \\
$\mathrm{Cr}$ & $135-12,000$ & $\mathrm{Sb}$ & $4.0-19,000$ \\
$\mathrm{Cu}$ & $70-210,000$ & $\mathrm{Sn}$ & $230-2600$ \\
$\mathrm{Fe}$ & $1300-637,000$ & $\mathrm{Ti}$ & $100-110,000$ \\
$\mathrm{~K}$ & $190-39,000$ & $\mathrm{Zn}$ & $120-27,300$ \\
\hline
\end{tabular}

Values in brackets refer to $\mathrm{PM}_{10}$ brake wear (Hildemann et al. 1991; Garg et al. 2000; Kennedy et al. 2002; Westerlund and Johansson 2002; Kennedy and Gadd 2003; Sanders et al. 2003; Von Uexküll et al. 2005; Schauer et al. 2006; Iijima et al. 2008) 
is present in road dust and atmospheric PM samples in the form of $\mathrm{Sb}$ (III) and $\mathrm{Sb}(\mathrm{V}) . \mathrm{Sb}_{2} \mathrm{~S}_{3}$ was also detected in some of the ambient $\mathrm{PM}_{10}$ samples despite the fact that it is easily decomposed into more stable compounds during the brake abrasion process. Table 3 provides an overview of the concentrations of the most common elements found in brake wear dust and $\mathrm{PM}_{10}$. Sometimes, brake dust samples appear to have lower concentrations of trace elements compared to airborne PM, probably due to higher volatilization of organic constituents in airborne PM compared to dust samples (Sanders et al. 2003). Regarding specific organic compounds, Rogge et al. (1993) reported that only a small fraction of the organic content of brake dust could be extracted and analysed by conventional laboratory techniques. Among the organic compounds detected, polyalkylene glycol ethers $(56.9 \%)$ and n-alkanoic acids $(34.3 \%)$ were the most abundant species, while n-alkanes, PAHs and substituted PAHs were also detected in trace concentrations. In conclusion, although the presence of species like transition metals and carbonaceous compounds in wear particles is confirmed, there is still much information missing particularly regarding the organic constituents of wear particles.

\section{Brake wear PM emission factors}

Emission factors (EFs) are used by researchers and regulating agencies as a tool to quantify the emission of a specified pollutant by an individual vehicle or a vehicle fleet mixture. They are functional relations that predict the quantity of a pollutant that is emitted per distance driven, energy consumed or amount of fuel used. EFs are typically derived for vehicle categories and depend on several parameters, the most important of which are the vehicle characteristics and emission control technologies, the type and quality of fuel used and the ambient and operating conditions (Franco et al. 2013). In order to determine EFs from brake wear, either direct measurement from the sources is employed, including real-world test conditions or laboratory experiments, or receptor modelling is applied. Although direct measurements provide EFs of a small number of vehicles, they have the advantage of being conducted under very well controlled conditions, even if in case of brake wear there is a difficulty in simulating real-life braking conditions. On the other hand, receptor modelling requires accurate knowledge of source composition and assumes that the sources specified are responsible for the species measured at the receptor (Barlow et al. 2007). A list of key tracers used by various researchers over the last decade for identifying brake wear is given in Table 4 . Sternbeck et al. (2002) proposed the ratio of $\mathrm{Cu} / \mathrm{Sb}(4.6 \pm 2.3)$ as typical of brake wear particles but differences often appear in the literature due to variations in brake pad composition and site characteristics (Adachi and Tainosho 2004; Hjortenkrans et al. 2007; Pant and Harrison 2013).

Regarding direct measurements, Garg et al. (2000) tested commercial pads used in light-duty vehicles and found $\mathrm{PM}_{10}$, $\mathrm{PM}_{2.5}$ and $\mathrm{PM}_{0.1}$ brake wear EFs of 2.9-7.5, 2.1-5.5 and 1.2$3.1 \mathrm{mg} \mathrm{km}^{-1} \mathrm{veh}^{-1}$, respectively. The upper limit of the range for $\mathrm{PM}_{10} \mathrm{EFs}$ was very close to the US EPA value of $7.9 \mathrm{mg} \mathrm{km}{ }^{-1} \mathrm{veh}^{-1}$ reported for light-duty petrol vehicles equipped with asbestos brakes (Boulter 2006). Sanders et al. (2003) also reported a relatively high average brake wear $\mathrm{PM}_{10}$ EF of $8.1 \mathrm{mg} \mathrm{km}^{-1} \mathrm{veh}^{-1}$ for low-metallic, semimetallic and NAO brake pads (Table 5). Somewhat lower EFs were reported by Iijima et al. (2008) who found a $\mathrm{PM}_{10}$ value of $5.8 \mathrm{mg} \mathrm{km}^{-1} \mathrm{veh}^{-1}$ and $\mathrm{PM}_{2.5}$ value of $3.9 \mathrm{mg} \mathrm{km}^{-1} \mathrm{veh}^{-1}$ in a study conducted with NAO brake pads. Overall, brake wear EFs for light-duty vehicles (LDVs) deriving from direct measurements fall in the range of $3.0-8.0 \mathrm{mg} \mathrm{km}^{-1} \mathrm{veh}^{-1}\left(\mathrm{PM}_{10}\right)$ and 2.1-5.5 $\mathrm{mg} \mathrm{km}^{-1} \mathrm{veh}^{-1}\left(\mathrm{PM}_{2.5}\right)$.

Abu-Allaban et al. (2003) employed the CMB receptor model in order to determine brake wear EFs of LDVs and heavy-duty vehicles (HDVs) at roadside locations in the USA. They calculated $\mathrm{PM}_{10}$ EFs of 0-80 mg km${ }^{-1} \mathrm{veh}^{-1}$ for LDVs and 0 $610 \mathrm{mg} \mathrm{km}^{-1} \mathrm{veh}^{-1}$ for HDVs. The corresponding $\mathrm{PM}_{2.5} \mathrm{EFs}$ were $0-5$ and $0-15 \mathrm{mg} \mathrm{km}^{-1} \mathrm{veh}^{-1}$. Higher brake wear EFs were observed at freeway exit sites, while brake emissions in highways and tunnels were negligible. Rauterberg-Wulff (1999) also

Table 4 Overview of most common key tracers used for brake wear emission calculation

\begin{tabular}{llll}
\hline Reference & Tracer & Reference & Tracer \\
\hline Sternbeck et al. 2002 & $\mathrm{Ba}, \mathrm{Cu}, \mathrm{Sb}$ & Gietl et al. 2010 & $\mathrm{Ba}, \mathrm{Cu}, \mathrm{Fe}, \mathrm{Sb}$ \\
Adachi and Tainosho 2004 & $\mathrm{Ba}, \mathrm{Ce}, \mathrm{Cu}, \mathrm{Fe}, \mathrm{La}, \mathrm{Sb}, \mathrm{Ti}, \mathrm{Y}, \mathrm{Zr}$ & Keuken et al. 2010 & $\mathrm{Cu}$ \\
Schauer et al. 2006 & $\mathrm{Ba}, \mathrm{Cu}, \mathrm{Fe}, \mathrm{Sb}, \mathrm{Si}, \mathrm{Zn}$ & Amato et al. 2011 & $\mathrm{Cu}, \mathrm{Cr}, \mathrm{Fe}, \mathrm{Sb}, \mathrm{Sn}, \mathrm{Zn}$ \\
Hjortenkrans et al. 2007 & $\mathrm{Cd}, \mathrm{Cu}, \mathrm{Pb}, \mathrm{Sb}, \mathrm{Zn}$ & Apeagyei et al. 2011 & $\mathrm{Cu}, \mathrm{Ba}, \mathrm{Fe}, \mathrm{Mo}, \mathrm{Ti}, \mathrm{Zr}$ \\
Harrison 2009 & $\mathrm{Ba}, \mathrm{Cu}$ & Duong and Lee 2011 & $\mathrm{Cu}, \mathrm{Ni}$ \\
Iijima et al. 2008 & $\mathrm{Sb}$ & Song and $\mathrm{Gao} 2011$ & $\mathrm{Sb}, \mathrm{Cu}, \mathrm{Fe}, \mathrm{Pb}$ \\
Tanner et al. 2008 & $\mathrm{Cu}, \mathrm{Cd}$ & Harrison et al. 2012 & $\mathrm{Sb}, \mathrm{Cu}, \mathrm{Fe}, \mathrm{Pb}$ \\
Bukowiecki et al. 2009a & $\mathrm{Cu}, \mathrm{Fe}, \mathrm{Mo}, \mathrm{Sb}, \mathrm{Sn}, \mathrm{Zn}, \mathrm{Zr}$ & Lawrence et al. 2013 & $\mathrm{Ba}, \mathrm{Cu}, \mathrm{Fe}, \mathrm{Mn}, \mathrm{Ni}, \mathrm{Pb}, \mathrm{Sb}$ \\
Dongarra et al. 2009 & $\mathrm{Cu}, \mathrm{Mo}, \mathrm{Sb}$ & Varrica et al. 2013 & $\mathrm{Sb}$ \\
\hline
\end{tabular}


Table 5 Brake wear $\mathrm{PM}_{10}$ emission factors found in the literature for LDVs (mg km $\left.{ }^{-1} \mathrm{veh}^{-1}\right)$

\begin{tabular}{lll}
\hline Reference & Type of study & Emission factor \\
\hline Garg et al. 2000 & Brake dynamometer study & $2.9-7.5$ \\
Sanders et al. 2003 & Brake dynamometer study & 8.1 \\
Iijima et al. 2008 & Brake dynamometer study & 5.8 \\
Rauterberg-Wulff 1999 & Receptor modelling (highway-tunnel) & 1.0 \\
Abu-Allaban et al. 2003 & Receptor modelling & $0-80$ \\
Luhana et al. 2004 & Receptor modelling & 8.8 \\
Bukowiecki et al. 2009a & Receptor modelling (urban street canyon) & 8.0 \\
Bukowiecki et al. 2009a & Receptor modelling (highway) & 1.6 \\
USEPA 1995 & Emission inventory & 7.9 \\
Lükewille et al. 2001 & Emission inventory & $1.8-4.9$ \\
Boulter et al. 2006 & Emission inventory (RAINS model) & 3.8 \\
Boulter et al. 2006 & Emissions inventory (CEPMEIP model) & 6.0 \\
Boulter et al. 2006 & Emissions inventory (MOBILE 6.2 model) & 7.8 \\
Barlow et al. 2007 & Emission inventory & $4.0-8.0$ \\
NAEI 2012 & Emission inventory & 7.0
\end{tabular}

reported very low $\mathrm{PM}_{10}$ brake wear EFs in tunnel studies (1.0 mg km${ }^{-1} \mathrm{veh}^{-1}$ for LDVs and $24.5 \mathrm{mg} \mathrm{km}^{-1} \mathrm{veh}^{-1}$ for HGVs). PMF was used at the APART project, and the EFs obtained were better complied with those of direct measurements. More specifically, $\mathrm{PM}_{10}$ brake wear EFs in an urban street canyon were found to be $8.0 \pm 4.0 \mathrm{mg} \mathrm{km}^{-1} \mathrm{veh}^{-1}$ (LDVs) and $81 \pm 39 \mathrm{mg} \mathrm{km}^{-1} \mathrm{veh}^{-1}$ (HDVs). EFs calculated at a highway sampling location turned out to be significantly lower $(1.6 \pm 1.1$ and $9.0 \pm 7.0 \mathrm{mg} \mathrm{km}^{-1} \mathrm{veh}^{-1}$ for LDVs and HDVs, respectively). PCA was employed during the PARTICULATES project, and a mean brake wear factor of $8.8 \mathrm{mg} \mathrm{km}^{-1} \mathrm{veh}^{-1}$ was derived in case of passenger vehicles (Luhana et al. 2004). NAEI provided more generalized exhaust and non-exhaust EFs by combining hot exhaust, cold start and evaporative emissions for each main vehicle type in the UK fleet averaged overall all road types. They calculated a $\mathrm{PM}_{10}$ brake wear EF of $7.0 \mathrm{mg} \mathrm{km}^{-1} \mathrm{veh}^{-1}$ (passenger cars), while for $\mathrm{PM}_{2.5}$, the corresponding value was $3.0 \mathrm{mg} \mathrm{km}^{-1} \mathrm{veh}^{-1}$ (NAEI 2012). For LGVs, they found EFs of $11 \mathrm{mg} \mathrm{km}^{-1} \mathrm{veh}^{-1}\left(\mathrm{PM}_{10}\right)$ and $4.0 \mathrm{mg} \mathrm{km}^{-1} \mathrm{veh}^{-1}\left(\mathrm{PM}_{2.5}\right)$. Barlow et al. (2007) reported total brake wear debris emission factors of 10-20 mg km ${ }^{-1} \mathrm{veh}^{-1}$ (LDVs) and 50$80 \mathrm{mg} \mathrm{km}^{-1} \mathrm{veh}^{-1}$ (HDVs), with however $40 \%$ of these becoming airborne $\left(\mathrm{PM}_{10}\right)$. This corresponds to $\mathrm{PM}_{10}$ EFs of 4 $8 \mathrm{mg} \mathrm{km}^{-1} \mathrm{veh}^{-1}$ for LDVs and 20-32 $\mathrm{mg} \mathrm{km}^{-1} \mathrm{veh}^{-1}$ for HDVs. Finally, RAINS, CEPMEIP and MOBILE 6.2 models used brake wear $\mathrm{PM}_{10}$ EFs of approximately 3.8, 6.0 and $7.8 \mathrm{mg} \mathrm{km}^{-1} \mathrm{veh}^{-1}$ for passenger cars, respectively. RAINS and CEPMEIP models also used $\mathrm{PM}_{2.5}$ EFs of approximately 2.2 and $6.0 \mathrm{mg} \mathrm{km}^{-1} \mathrm{veh}^{-1}$, respectively (Berdowski et al. 2001; Boulter et al. 2006; CEPMEIP 2012). Concluding, brake wear EFs for LDVs deriving from modelling fall in the range of 1.0 $8.8 \mathrm{mg} \mathrm{km}^{-1} \mathrm{veh}^{-1}\left(\mathrm{PM}_{10}\right)$, depending on the site.

\section{Health relevance of brake wear particles}

Several key factors (i.e. size distribution, agglomeration state, chemical composition, surface area, chemistry and charge) need to be taken into account when investigating wear particle toxicity (Oberdörster et al. 2005), among which particle size and chemical composition seem to be the most important. Many studies have demonstrated that particle size affects particle deposition in the respiratory tract (Kumar et al. 2013; Poepping and Ginda 2010; Pope et al. 2002; Samet et al. 2000). Coarse particles are mainly deposited in the upper respiratory tract (nose and throat), while ultrafine particles penetrate deep into the lungs (Poepping and Ginda 2010), thus posing hazards related to oxidative stress and inflammation (Balakrishna et al. 2009; Karlsson et al. 2005; Oberdörster et al. 2005). They can also enhance early atherosclerosis, partly due to their high content in redox chemicals and their ability to synergize with known proatherogenic mediators in the promotion of tissue oxidative stress (Araujo and Nel 2009). Other studies have shown that ultrafine particles may become blood-borne and translocate to other tissues such as the liver, kidneys and brain (Geiser and Kreyling 1999; Oberdörster et al. 2005), while experiments to animals have shown translocation of inhaled ultrafine particles to the brain (Tjalve and Henriksson 1999). A considerable fraction of brake wear particles lie into diameters smaller than $100 \mathrm{~nm}$ (Garg et al. 2000; Kukutschová et al. 2011; Mathissen et al. 2011), thus posing concerns regarding its potential adverse health effects. The World Health Organization reported that adverse health effects of inhalable PM are due to exposure over both short (hours, days) and long (months, years) terms and include respiratory and cardiovascular morbidity as well 
as mortality from cardiovascular and respiratory diseases and from lung cancer (WHO 2013). However, there are still no comprehensive studies directly linking brake wear PM with adverse effects on human health.

Chemical composition of particles can also be an important factor causing adverse effects on human health. Several $\mathrm{PM}_{2.5}$ constituents - attached to black carbon - have been seen as responsible for adverse impacts, with the most important being PAHs, metals and inorganic salts (WHO 2013). Transition metals such as $\mathrm{Fe}, \mathrm{Cu}, \mathrm{Ni}$ and $\mathrm{Cr}$ are important due to their potential to produce reactive oxygen species (ROS) and therefore oxidative stress in biological tissues. Oxidative stress occurs when antioxidant systems are overwhelmed by oxidative processes. Oxidative stress can also result from redox cycling by semiquinone radicals from organic compounds adsorbed on the particles and from ROS produced by activated macrophages (Karlsson et al. 2005). Metals such as Zn, Al and $\mathrm{Pb}$ can also influence the toxic effects of transition metals either by enhancing or by lessening their activity (Kelly and Fussell 2012). Brake wear emissions are characterized by high $\mathrm{Fe}$ and $\mathrm{Cu}$ concentrations and therefore should be considered even though available data don not allow quantification of specific health impacts on the population level. Apart from transition metals, there are other elements which have been linked to negative responses. Epidemiology studies revealed a high correlation between blood $\mathrm{Pb}$ and cardiovascular mortality and morbidity (Schober et al. 2006), while $\mathrm{Cu}$ and $\mathrm{S}$ have been associated with increased monthly mortality (Pope et al. 2007). Burnett et al. (2000) found an association of Fe, Ni and $\mathrm{Zn}$ in $\mathrm{PM}_{2.5}$ with short-term mortality, while they reported that the total effect of these components was greater than that of the mass alone. Ostro et al. (2007) linked fine particle $\mathrm{Ca}, \mathrm{Cu}$, $\mathrm{Fe}, \mathrm{Zn}, \mathrm{Mn}, \mathrm{Pb}$, Ti and $\mathrm{V}$ with daily mortality, while Hirshon et al. (2008) associated previous-day fine particle $\mathrm{Zn}$ concentrations with increased paediatric asthma cases. Toxicology studies in healthy volunteers have associated neutrophilic inflammation in the lungs with $\mathrm{Fe}$ and $\mathrm{Se}$ (Ghio et al. 2000; Huang et al. 2003). Fe particle agglomerates have been linked to inflammatory responses, decreased transferrin concentrations and increased concentrations of ferritin and lactoferrin in the blood (Ghio et al. 1998). Pulmonary injury and inflammation were connected to high concentrations of $\mathrm{Fe}, \mathrm{Cu}, \mathrm{Ni}, \mathrm{Pd}$ and $\mathrm{Zn}$ (Ghio et al. 2004), while Schaumann et al. (2004) reported a higher inflammatory effect in the lungs of healthy volunteers following metal-rich particle (high levels of $\mathrm{Zn}$, $\mathrm{Cu}, \mathrm{Ni}$ and $\mathrm{Ca}$ ) instillation compared with fractions with a lower metal content (Kelly and Fussell 2012). $\mathrm{Sb}_{2} \mathrm{O}_{3}$ has been classified as a possible human lung carcinogen by the International Agency for Research on Cancer (IARC 1989; Varrica et al. 2013) and as a "Class 3 Carcinogen" via dust inhalation according to 67/548/EC and amendments. Numerous studies have shown high concentrations of most of these metals in airborne brake wear particles (Furuta et al. 2005; Garg et al.
2000; Gasser et al. 2009; Gietl et al. 2010; Hjortenkrans et al. 2007; Kukutschová et al. 2011; Iijima et al. 2007; Pant and Harrison 2013; Sanders et al. 2003; Wahlström 2009); therefore, the possibility that such particles may induce adverse health impacts to humans should not be excluded.

Besides studies which investigate adverse health effects of PM, there are studies which have focused on potential adverse effects of brake wear particles. Gasser et al. (2009) exposed cells directly to freshly emitted wear particles in order to investigate their toxic effects on lung cells in vitro. Their results suggest that the metallic content of brake particles (specifically $\mathrm{Fe}, \mathrm{Cu}$ and $\mathrm{Mn}$ ) damage tight junctions both in "normal deceleration" and "full stop" braking pattern, probably through a mechanism involving oxidative stress. Brake wear particles derived from "full stop" braking also cause proinflammatory responses in lung cells, probably through a mechanism involving organic compounds and black carbon. This is enhanced by the study of Mazzarella et al. (2007) who also found a significant correlation between increased proinflammatory responses and high concentrations of carbon in the small particle size range. Riediker et al. (2004) linked adverse health responses to a particle source with a brake wear signature. They reported that fine particles originating from speed-changing traffic modulates the autonomic control of the heart rhythm, increases the frequency of premature supraventricular beats and elicits pro-inflammatory and pro-thrombotic responses in young, healthy, non-smoking men. They proposed that these health effects might be associated with the levels of $\mathrm{Cu}$, which strongly increased under speed-changing traffic conditions and was associated with brake abrasion. Additionally, the researchers pointed out that long-term cardiovascular risk cannot be excluded, especially when considering the reported increase in myocardial infarction among professional drivers and the increase in mortality among people living near major roadways.

\section{Conclusions}

The main points which can be drawn from the present literature study are summarized below:

- Exhaust and non-exhaust sources contribute almost equally to total traffic-related $\mathrm{PM}_{10}$ emissions. Brake wear has been recognized as one of the most important non-exhaust traffic-related source, with its relative contribution to nonexhaust traffic-related emissions ranging between 16 and $55 \%$ and to total traffic-related $\mathrm{PM}_{10}$ emissions between 11 and $21 \%$.

- It is estimated that approximately $50 \%$ of total brake wear is emitted as airborne $\mathrm{PM}_{10}$. The rest may deposit on the road or nearby or maybe attracted by the vehicle. The fate of bigger particles has not yet been well investigated. 
- Several factors affect both physicochemical characteristics and generation rates of brake wear particles, making it very difficult to understand the generation mechanisms and study the properties of brake wear particles. Furthermore, there is a wide variety of sampling methodologies and measurement techniques which very often result in non-comparable results.

- Brake wear $\mathrm{PM}_{10}$ usually displays a unimodal mass size distribution with maxima between 2 and $6 \mu \mathrm{m}$. Particle number distributions of brake wear $\mathrm{PM}_{10}$ appear to be bimodal with both peaks lying within the fine mode. Most researchers report one peak of the distribution being among ultrafine particles $(<100 \mathrm{~nm})$, while others find it at somewhat bigger sizes (approximately $300 \mathrm{~nm}$ )

- The most important chemical constituents of brake wear are $\mathrm{Fe}, \mathrm{Cu}, \mathrm{Ba}$ and $\mathrm{Pb}$. Organic carbon is also present in significantly higher concentrations compared to elemental carbon. On the other hand, there is very limited information regarding specific organic constituents of brake wear $\mathrm{PM}_{10}$.

- Brake wear $\mathrm{PM}_{10}$ emission factors of 2.0$8.0 \mathrm{mg} \mathrm{km}^{-1} \mathrm{veh}^{-1}$ for LDVs have been reported. Most studies find $\mathrm{PM}_{10}$ EFs of approximately 6.0$7.0 \mathrm{mg} \mathrm{km}^{-1} \mathrm{veh}^{-1}$, which is very close to the standard for exhaust emissions of Euro 5/6 diesel vehicles. Brake wear $\mathrm{PM}_{10}$ EFs of HDVs are approximately one order of magnitude higher than of LDVs. Most commonly used key tracers of brake wear are $\mathrm{Cu}$ and $\mathrm{Sb}$.

- Brake wear contains particles from all fractions involved in the respiratory function. Additionally, some constituents of airborne brake wear particles have been recognized as dangerous or potentially dangerous for the human health. However, there are no comprehensive studies linking brake wear particles with adverse effects on human health, while it is difficult to extrapolate animal and in vitro studies to humans.

Open Access This article is distributed under the terms of the Creative Commons Attribution License which permits any use, distribution, and reproduction in any medium, provided the original author(s) and the source are credited.

\section{References}

Abu-Allaban M, Gillies JA, Gertler AW, Clayton R, Proffitt D (2003) Tailpipe, resuspended road dust, and brake-wear emission factors from on-road vehicles. Atmos Environ 37:5283-5293

Adachi K, Tainosho Y (2004) Characterization of heavy metal particles embedded in tire dust. Environ Int 30:1009-1017

Amato F, Pandolfi M, Escrig A, Querol X, Alastuey A, Pay J, Perez N, Hopke PK (2009) Quantifying road dust resuspension in urban environment by multilinear engine: a comparison with PMF2. Atmos Environ 43:2770-2780
Amato F, Querol X, Johansson C, Nagl C, Alastuey A (2010) A review on the effectiveness of street sweeping, washing and dust suppressants as urban PM control methods. Sci Total Environ 408:3070 3084

Amato F, Pandolfi M, Moreno T, Furger M, Pey J, Alastuey A, Bukowiecki N, Prevot ASH, Baltensberger U, Querol X (2011) Sources and variability of inhalable road dust particles in three European cities. Atmos Environ 45:6777-6787

Amato F, Cassee FR, Denier Van der Gon H, Gehrig R, Gustafsson M, Hafner W, Harrison R, Jozwicka M, Kelly F, Moreno T, Prevot ASH, Schaap M, Sunyer J, Querol X (2014) Urban air quality: the challenge of traffic non-exhaust emissions. J Hazard Mater 275:3136

Apeagyei E, Bank MS, Spengler JD (2011) Distribution of heavy metals in road dust along an urban-rural gradient in Massachusetts. Atmos Environ 45:2310-2323

Araujo JA, Nel AE (2009) Particulate matter and atherosclerosis: role of particle size, composition and oxidative stress. Part Fibre Toxicol 6(24)

Balakrishna S, Lomnicki S, McAvey KM, Cole RB, Dellinger B, Cormier SA (2009) Environmentally persistent free radicals amplify ultrafine particle mediated cellular oxidative stress and cytotoxicity. Parta Fibre Toxicol 6(11)

Barlow TJ, Boulter PG, McCrae IS, Sivell P, Harrison RM, Carruthers D, Stocker J (2007) Non-exhaust particulate matter emissions from road traffic: summary report. TRL report for DEFRA. Scottish Executive. Welsh Assembly Government. DoENI

Berdowski J, Visschedijk AJH, Creemers E, Pullus T, Pacyna J, Fudala J, Querreveld D (2001) CEMPMEIP database particulate matter 1995. TNO Institute of Environmental Sciences Energy Research and Process Innovation. Apeldoorn, The Netherlands

Bodel K, Ostermeyer GP (2014) A comprehensive approach for the simulation of heat and heat-induced phenomena in friction materials. Wear 311:47-56

Boulter PG (2006) A review of emission factors and models for road vehicle non-exhaust particulate matter. TRL report PPR065. TRL Limited, Wokingham

Boulter PG, Thorpe A, Harrison R, Allen A (2006) Road vehicle nonexhaust particulate matter: final report on emission modellingpublished project report PPR110. TRL limited, Wokingham

Bukowiecki N, Gehrig R, Lienemann P, Hill M, Figi R, Buchmann B, Furger M, Richard A, Mohr C, Weimer S, Prévôt A, Baltensperger U (2009a) PM10 emission factors of abrasion particles from road traffic (APART). Swiss Association of Road and Transportation Experts (VSS)

Bukowiecki N, Lienemann P, Hill M, Figi R, Richard A, Furger M, Rickers K, Falkenberg G, Zhao Y, Cliff S, Prevot A, Baltensberger U, Buchmann B, Gehrig R (2009b) Real-world emission factors for antimony and other brake wear related trace elements: sizesegregated values for light and heavy duty vehicles. Environ Sci Technol 43:8072-8078

Burnett RT, Brook J, Dann T, Delocla C, Philips O, Cakmak S, Vincent R, Goldberg MS, Krewski D (2000) Association between particulateand gas-phase components of urban air pollution and daily mortality in eight Canadian cities. Inhal Toxicol 12:15-39

CEPMEIP (2012) Cepmeip database. Available from: http://www.air.sk/ tno/cepmeip/ (retrieved 16.07.14)

Cha S, Carter P, Bradow R (1983) Simulation of automobile brake wear dynamics and estimation of emissions. SAE Technical Paper 83-1036

Chan D, Stachowiak GW (2004) Review of automotive brake friction materials. Proc Inst Mech Eng Part D: J Automob Eng 218:953-966

Dahl A, Gharibi A, Swietlicki E, Gudmundsson A, Bohgard M, Ljungman A, Blomqvist G, Gustafsson M (2006) Trafficgenerated emissions of ultrafine particles from pavement-tire interface. Atmos Environ 40:1314-1323 
Denby BR, Sundvor I, Johansson C, Pirjola L, Ketzel M, Norman M, Kupiainen K, Gustafsson M, Blomqvist G, Omstedt G (2013) A coupled road dust and surface moisture model to predict non-exhaust road traffic induced particle emissions (NORTRIP), Part 1: road dust loading and suspension modeling. Atmos Environ 77:283-300

Denier van der Gon H, Hulskotte H, Visschedijk AJH, Schaap M (2007) A revised estimate of copper emissions from road transport in UNECE-Europe and its impact on predicted copper concentrations. Atmos Environ 41:8697-8710

Denier Van der Gon H, Gerlofs-Nijland M, Gehrig R, Gustafsson M, Janssen N, Harrison R, Hulskotte J, Johansson C, Jozwicka M, Keuken M, Krijgsheld K, Ntziachristos L, Riediker M, Cassee F (2013) The policy relevance of wear emissions from road transport, now and in the future - an international workshop report and consensus statement. J Air Waste Manag Assoc 63:136-149

Dongarra G, Manno E, Varrica D (2009) Possible markers of trafficrelated emissions. Environ Monit Assess 154:117-125

Duong TT, Lee BK (2011) Determining contamination level of heavy metals in road dust from busy traffic areas with different characteristics. J Environ Manag 92:554-562

Eriksson M, Lord J, Jacobson S (2001) Wear and contact conditions of brake pads: dynamical in situ studies of pad on glass. Wear 249: 272-278

Eriksson M, Bergman F, Jacobson S (2002) On the nature of tribological contact in automotive brakes. Wear 252:26-36

Fabretti JF, Sauret N, Gal JF, Maria PC, Schärer U (2009) Elemental characterization and source identification of $\mathrm{PM}_{2.5}$ using positive matrix factorization: the Malraux road tunnel, Nice, France. Atmos Res 94:320-329

Figi R, Nagel O, Tuchschmid M, Lienemann P, Gfeller U, Bukowiecki N (2010) Quantitative analysis of heavy metals in automotive brake linings: a comparison between wet-chemistry based analysis and insitu screening with a handheld X-ray fluorescence spectrometer. Anal Chim Acta 676(1-2):46-52

Franco V, Kousoulidou M, Muntean M, Ntziachristos L, Hausberger S, Dilara P (2013) Road vehicle emission factors development: a review. Atmos Environ 70:84-97

Furusjö E, Sternbeck J, Cousins AP (2007) PM10 source characterization at urban and highway roadside locations. Sci Total Environ 387(13):206-219

Furuta N, Iijima A, Kambe A, Sakai K, Sato K (2005) Concentrations, enrichment and predominant sources of $\mathrm{Sb}$ and other trace elements in size classified airborne particulate matter collected in Tokyo from 1995 to 2004. J Environ Monit 7:1155-1161

Gadd J, Kennedy P (2000). Preliminary examination of organic compounds present in tyres, brake pads and road bitumen in New Zealand: prepared for the Ministry of Transport by Kingett Mitchell Limited

Garg BD, Cadle SH, Mulawa PA, Groblicki PJ (2000) Brake wear particulate matter emissions. Environ Sci Technol 34:4463-4469

Gasser M, Riediker M, Mueller L, Perrenoud A, Blank F, Gehr P, RothenRutishauser B (2009) Toxic effects of brake wear particles on epithelial lung cells in vitro. Part Fibre Toxicol 6(30)

Geiser M, Kreyling WG (1999) Deposition and biokinetics of inhaled nanoparticles. Part Fiber Toxicol 7(2)

Ghio AJ, Carter JD, Richards JH, Brighton LE, Lay JC, Devlin RB (1998) Disruption of normal iron homeostasis after bronchial instillation of an iron-containing particle. Am J Physiol 274:L396-L403

Ghio AJ, Kim C, Devlin RB (2000) Concentrated ambient air particles induce mild pulmonary inflammation in healthy human volunteers. Am J Respir Crit Care Med 162:981-988

Ghio AJ, Churg A, Roggli VL (2004) Ferruginous bodies: implications in the mechanism of fiber and particle toxicity. Toxicol Pathol 32:643-649

Gietl JK, Lawrence R, Thorpe AJ, Harrison RM (2010) Identification of brake wear particles and derivation of a quantitative tracer for brake dust at a major road. Atmos Environ 44:141-146
Gustafsson M, Blomqvist G, Gudmundsson A, Dahl A, Swietlicki E, Bohgard M, Lindbom J, Ljungman A (2008) Properties and toxicological effects of particles from the interaction between tyres, road pavement and winter traction material. Sci Total Environ 393:226240

Harrison, R.M. (2009). Airborne particulate matter from road traffic: current status of knowledge and research challenges paper presented at the ETTAO09. In: 17th Transport and Air Pollution Symposium e 3rd Environment and Transport Symposium

Harrison RM, Jones AM, Gietl J, Yin J, Green DC (2012) Estimation of the contributions of brake dust, tire wear, and resuspension to nonexhaust traffic particles derived from atmospheric measurements. Environ Sci Technol 46:6523-6529

Hildemann LM, Markowski GR, Cass GR (1991) Chemical-composition of emissions from urban sources of fine organic aerosol. Environ Sci Technol 25:744-759

Hirshon J, Shardell M, Alles S, Powell J, Squibb K, Ondov J, Blaisdell KJ (2008) Elevated ambient air zinc increases pediatric asthma morbidity. Environ Health Perspect 116:826-831

Hjortenkrans DST, Bergback BG, Haggerud AV (2007) Metal emissions from brake linings and tires: case studies of Stockholm, Sweden 1995/1998 and 2005. Environ Sci Technol 41:5224-5230

Huang YC, Ghio AJ, Stonehuerner J, McGee J, Carter JD, Grambow SC, Devlin RB (2003) The role of soluble components in ambient fine particles-induced changes in human lungs and blood. Inhal Toxicol $15: 327-342$

IARC (1989). Some organic solvents, resin monomers and related compounds, pigments and occupational exposures in paint manufacture and painting. International Agency for Research on Cancer Monograph, Volume 47, Lyon, France, pp. 291-305

Iijima A, Sato K, Yano K, Kato M, Tago H, Kato M, Kimura H, Furuta N (2007) Particle size and composition distribution analysis of automotive brake abrasion dusts for the evaluation of antimony sources of airborne particulate matter. Atmos Environ 41:4908-4919

Iijima A, Sato K, Yano K, Kato M, Kozawa K, Furuta N (2008) Emission factor for antimony in brake abrasion dust as one of the major atmospheric antimony sources. Environ Sci Technol 42:2937-2942

Karlsson HL, Nilsson L, Moller L (2005) Subway particles are more genotoxic than street particles and induce oxidative stress in cultured human lung cells. Chem Res Toxicol 18:19-23

Kelly FJ, Fussell JC (2012) Size, source and chemical composition as determinants of toxicity attributable to ambient particulate matter. Atmos Environ 60:504-526

Kennedy P, Gadd J (2003) Preliminary examination of trace elements in tyres, brake pads, and road bitumen in New Zealand. Prepared for the New Zealand Ministry of Transport and Infrastructure Auckland

Kennedy K, Gadd J, Moncrieff I (2002) Emission factors for contaminants released by motor vehicles in New Zealand. Prepared for the New Zealand Ministry of Transport and Infrastructure Auckland

Ketzel M, Omstedt G, Johansson C, During I, Pohjola M, Oettl D, Gidhagenb L, Wåhlina P, Lohmeyere A, Haakanaf M, Berkowicz $R$ (2007) Estimation and validation of $\mathrm{PM}_{2.5} / \mathrm{PM}_{10}$ exhaust and nonexhaust emission factors for practical street pollution modelling. Atmos Environ 41:9370-9385

Keuken M, Denier van der Gon H, van der Valk K (2010) Non-exhaust emissions of PM and the efficiency of emission reduction by road sweeping and washing in the Netherlands. Sci Total Environ 408: 4591-4599

Kukutschová J, Moravec P, Tomášek V, Matějka V, Smolík J, Schwarz J, Seidlerová J, Šafářová K, Filip P (2011) On airborne nano/microsized wear particles released from low-metallic automotive brakes. Environ Pollut 159:998-1006

Kumar P, Pirjola L, Ketzel M, Harrison RM (2013) Nanoparticle emissions from 11 non-vehicle exhaust sources - a review. Atmos Environ 67:252-277 
Kwak JH, Kim H, Lee J, Lee S (2013) Characterization of non-exhaust coarse and fine particles from on-road driving and laboratory measurements. Sci Total Environ 458-460:273-282

Lawrence S, Sokhi R, Ravindra K, Mao H, Prain HD, Bull ID (2013) Source apportionment of traffic emissions of particulate matter using tunnel measurements. Atmos Environ 77:548-557

Lemen RA (2004) Asbestos in brakes: exposure and risk of disease. Am J Ind Med 45:229-237

Liew KW, Nirmal U (2013) Frictional performance evaluation of newly designed brake pad materials. Mater Des 48:25-33

Lipfert FW, Wyzga RE, Baty JD, Miller JP (2006) Traffic density as a surrogate measure of environmental exposures in studies of air pollution health effects: long-term mortality in a cohort of US veterans. Atmos Environ 40:154-169

Luhana L, Sokhi R, Warner L, Mao H, Boulter P, McCrae I, Wright J, Osborn D (2004) Characterisation of exhaust particulate emissions from road vehicles. FP5 Particulates Project

Lükewille A, Bertok I, Amann M, Cofala J, Gyarfas F, Heyes C, Karvosenoja N, Klimont Z, Schopp W (2001) A framework to estimate the potential and costs for the control of fine particulate emissions in Europe, IIASA Interim Report IR-01023. International Institute for Applied Systems Analysis, Laxenburg, Austria

Mathissen M, Scheer V, Vogt R, Benter T (2011) Investigation on the potential generation of ultrafine particles from the tire-road interface. Atmos Environ 45:6172-6179

Mazzarella G, Ferraraccio F, Prati MV, Annunziata S, Bianco A, Mezzogiorno A, Liguori G, Angelillo IF, Cazzola M (2007) Effect of diesel exhaust particles on human lung epithelial cells: an in vitro study. Respir Med 101:1155-1162

Mosleh M, Blau PJ, Dumitrescu D (2004) Characteristics and morphology of wear particles from laboratory testing of disc brake materials. Wear 256:1128-1134

NAEI (2012) Road transport emission factors from 2010 NAEI. Available at http://naei.defra.gov.uk/datawarehouse/3_9_323 136259 roadtransportefs naei10 v2.xls (retrieved 16.07.14)

Napier F, D'A Arcy B, Jefferies C (2008) A review of vehicle related metals and polycyclic aromatic hydrocarbons in the UK environment. Desalination 226:143-150

Oberdörster G, Oberdörster E, Oberdörster J (2005) Nanotoxicology: an emerging discipline evolving from studies of ultrafine particles. Environ Health Perspect 113:823-839

Olofsson U, Olander L (2013) On the identification of wear modes and transitions using airborne wear particles. Tribol Int 59:104-113

Oesterle W, Dmitriev A (2014) Some Considerations on the Role of Third Bodies during Automotive Braking. SAE Int J Passeng Cars-Mech Syst 7(4):2014-01-2490

Österle W, Urban I (2006) Third body formation on brake pads and rotors. Tribol Int 39:401-408

Österle W, Griepentrog M, Gross T, Urban I (2001) Chemical and microstructural changes induced by friction and wear of brakes. Wear 251:1469-1476

Ostermeyer GP (2001) Friction and wear of brake systems. Forsch Ingenieurwes 66:267-272

Ostermeyer GP (2007) The mesoscopic particle approach. Tribol Int 40(6):953-959

Ostermeyer GP, Muller M (2008) New insights into the tribology of brake systems. Proc Inst Mech Eng Part D: J Automob Eng 222:11671200

Ostro B, Broadwin R, Green S, Feng WY, Lipsett M (2006) Fine particulate air pollution and mortality in nine California counties: results from CALFINE. Environ Health Perspect 114:29-33

Ostro B, Feng WY, Broadwin R, Green S, Lipsett M (2007) The effects of components of fine particulate air pollution on mortality in California: results from CALFINE. Environ Health Perspect 115: 13-19
Pant P, Harrison RM (2013) Estimation of the contribution of road traffic emissions to particulate matter concentrations from field measurements: a review. Atmos Environ 77:78-97

Peikertová P, Kukutschová J, Vávra I, Matějka V, Životský O, Vaculík M, Lee PW, Filip P (2013) Water suspended nanosized particles released from nonairborne brake wear debris. Wear 306:89-96

Poepping, N. and Ginda, J (2010) Adverse health effects of diesel particle air pollution. An overview for the DEM Clean Diesel Workshops. Diesel Workshop presentations Rhodes February 2010

Pope CA, Burnett RT, Thun MJ, Calle EE, Krewski D, Ito K, Thurston GD (2002) Lung cancer, cardiopulmonary mortality, and long-term exposure to fine particulate air pollution. J Am Med Assoc 287: 1132-1141

Pope CA III, Rodermund DL, Gee MM (2007) Mortality effects of a copper smelter strike and reduced ambient sulfate particulate matter air pollution. Environ Health Perspect 115:679-683

Querol X, Alastuey A, Ruiz CR, Artiñano B, Hansson HC, Harrison RM, Buringh E, Ten Brink HM, Lutz M, Bruckmann P, Straeh P, Schneider J (2004) Speciation and origin of $\mathrm{PM}_{10}$ and $\mathrm{PM}_{2.5}$ in selected European cities. Atmos Environ 38:6547-6555

Rauterberg-Wulff, A. (1999) Determination of emission factors for tyre wear particles up to $10 \mu \mathrm{m}$ by tunnel measurements. Proceedings of 8th International Symposium 'Transport and Air Pollution', Graz, Austria, 31 May - 2 June 1999

Riediker M, Devlin RB, Griggs TR, Herbst MC, Bromberg PA, Williams RW, Casci WE (2004) Cardiovascular effects in patrol officers are associated with fine particulate matter from brake wear and engine emissions. Particle and Fibre Toxicology 1(2)

Riediker M, Gasser M, Perrenoud A, Gehr P, Rothen-Rutishauser B (2008) A system to test the toxicity of brake wear particles. 12th International ETH-Conference on Combustion Generated Nanoparticles, 23-25 June 2008, Zurich, Switzerland

Rogge WF, Hildemann LM, Marurek MA, Cass GR (1993) Sources of fine organic aerosol. 3. Road dust, tire debris, and organometallic brake lining dust: roads as sources and sinks. Environ Sci Technol 27:1892-1904

Roubicek V, Raclavska H, Juchelkova D, Filip P (2008) Wear and environmental aspects of composite materials for automotive braking industry. Wear 265(1-2): 167-75

Samet JM, Dominici F, Curriero FC, Coursac I, Zeger SL (2000) Fine particulate air pollution and mortality in 20 U.S. cities, 1987-1994. N Engl J Med 343:1742-1749

Sanders PG, Xu N, Dalka TM, Maricq MM (2003) Airborne brake wear debris: size distributions, composition, and a comparison of dynamometer and vehicle tests. Environ Sci Technol 37:4060-4069

Schauer JJ, Lough GC, Shafer MM, Christensen WC, Arndt MF, DeMinter JT, Park JS (2006) Characterization of emissions of metals emitted from motor vehicles. Research report 133, Health Effects Institute

Schaumann F, Borm PJ, Herbrich A, Knoch J, Pitz M, Schins RP, Luettig B, Hohlfeld JM, Heinrich J, Krug N (2004) Metal-rich ambient particles (Particulate Matter2.5) cause airway inflammation in healthy subjects. Am J Respir Crit Care Med 170:898-903

Schober SE, Mirel LB, Graubard BI, Brody DJ, Flegal KM (2006) Blood lead levels and death from all causes, cardio vascular disease, and cancer: results from the NHANES III mortality study. Environ Health Perspect 114:1538-1541

Sjödin A, Ferm M, Björk A, Rahmberg M, Gudmundsson A, Swietlicki E, Johansson C, Gustafsson M, Blomqvist G (2010) Wear Particles from Road Traffic: A Field, Laboratory and Modelling Study. IVL Swedish Environmental Research Institute Ltd., Göteborg

Söderberg A, Sellgren U, Andersson S (2008) Using finite element analysis to predict the brake pressure needed for 
effective rotor cleaning in disc brakes. Document 2008-012565. 26th SAE Brake Colloquium and Exhibition, October 2008, San Antonio, TX

Song F, Gao Y (2011) Size distributions of trace elements associated with ambient particular matter in the affinity of a major highway in the New Jersey-New York metropolitan area. Atmos Environ 45:6714 6723

Sternbeck J, Sjodin A, Andreasson K (2002) Metal emissions from road traffic and the influence of resuspension - results from two tunnel studies. Atmos Environ 36:4735-4744

Tanner PA, Hoi-Ling M, Yu PKN (2008) Fingerprinting metals in street dust in Beijing, Shanghai and Hong Kong. Environ Sci Technol 42: 7111-7117

Thorpe A, Harrison RM (2008) Sources and properties of non-exhaust particulate matter from road traffic: a review. Sci Total Environ 400: 270-282

Tjalve H, Henriksson J (1999) Uptake of metals in the brain via olfactory pathways. Neurotoxicology 20:181-195

USEPA (1995) Compilation of air pollution emission factors. Vol.1 and Vol.2, AP-42, 5th edition

Varrica D, Bardelli F, Dongarrà G, Tamburo E (2013) Speciation of Sb in airborne particulate matter, vehicle brake linings, and brake pad wear residues. Atmos Environ 64:18-24

von Uexküll O, Skerfving S, Doyle R, Braungart M (2005) Antimony in brake pads: a carcinogenic component? J Clean Prod 13:19-31

Wåhlin P, Berkowicz R, Palmgren F (2006) Characterisation of trafficgenerated particulate matter in Copenhagen. Atmos Environ 40: 2151-2159
Wahlström J (2009) Towards a simulation methodology for prediction of airborne wear particles from disc brakes: licentiate thesis. Department of Machine Design Royal Institute of Technology, Stockholm, ISBN 978-91-7415-391-0

Wahlström J (2011) A study of airborne wear particles from automotive disc brakes: doctoral thesis. Department of Machine Design Royal Institute of Technology, Stockholm, ISBN 978-91-7415-871-7

Wahlström J, Olander L, Olofsson U (2010a) Size, shape, and elemental composition of airborne wear particles from disc brake materials. Tribol Lett 38:15-24

Wahlström J, Söderberg A, Olander L, Jansson A, Olofsson U (2010b) A pin-on-disc simulation of airborne wear particles from disc brakes. Wear 268:763-769

Westerlund KG (2001) Metal emissions from Stockholm traffic — wear of brake linings. The Stockholm Environment and Health Protection Administration, 10064, Stockholm, Sweden

Westerlund KG, Johansson C (2002) Emission of metals and particulate matter due to wear of brake linings in Stockholm. Adv Air Pollut Ser 10:793-802

WHO, World Health Organization (2013) Health effects of particulate matter. Policy implications for countries in eastern Europe, Caucasus and central Asia

Wik A, Dave G (2009) Occurrence and effects of tire wear particles in the environment - a critical review and an initial risk assessment. Environ Pollut 157:1-11

Yu D, Xu M, Yao H, Liu X, Zhou K, Li L, Wen C (2009) Mechanisms of the central mode particle formation during pulverized coal combustion. Proc Combust Inst 32:2075-2082 